\title{
Description of Research Design using Articles for Biometrics Technology Security and Countermeasures
}

\author{
Irfan Iqbal \\ Department of Natural and Applied Sciences, Buraydah Community College, Qassim University, Saudi Arabia \\ e.eqbal@qu.edu.sa
}

\begin{abstract}
In this paper, we search different articles and journals by using different scientific databases (Elsevier, Emerald, IEEE, Springer and ACM). The selection of relevant articles and journals is made through proper study of the relevant material's abstract, conclusion with respect to our problem domain. After that, selected articles/papers are motivated by various arguments that depend upon the investigated area and develop motivation for the results.
\end{abstract}

Key words: Biometrics Technology, Authentication system, Research design, Article selection, Biometrics Security \& Privacy

\section{INTRODUCTION}

Biometrics measure individual's unique physical or behavioral characteristics to recognize or authenticate their identity. Common physical biometrics include fingerprints; hand or palm geometry, retina, iris, or facial characteristics. Behavioral characters include signature, voice (which also has a physical component).

Most commonly, security field uses three different types of authentication:

Something you know: Password, PIN, etc Something you have: card key, smart card, etc Something you are- $-\mathrm{a}$ Biometric

A biometric is the most secure and convenient authentication tool. It can't be borrowed, stolen, or forgotten, and forging one is practically impossible.

In this paper, our focus was on "Biometric Technology Security concerns and its countermeasures". The division of the title is made by observing its depth and wideness. So the

1st Division: covers the Biometric Security concerns like factors influencing the adoption of Biometric security technologies by decision making when trying to adopt biometric security technology solutions. 2nd Division: Covers the Biometric Security Attacks and its countermeasures. In other words, analyzing biometric authentication's weakness to various spoofing attacks, and efforts to defeat the spoofing attack are presented.

Both of the division are being treated parallel to make sure of the search process. Firstly, we designed research questions and after that keywords are derived by conducting a search on different scientific databases. The exact selection of relevant articles/papers is made through its inclusion and exclusion criteria.

\section{STRATEGY}

Before defining the strategy of finding the articles/papers that mostly related to our research area, firstly we formulate the questions that does relate to our research area. Final Stage

\subsection{Research Questions}

RQ1: What are the different attacks related to biometrics authentication system?

RQ2: What are the different spoofing methodologies?

RQ3: What steps are useful against the spoofing techniques?

RQ4: Factors influencing the adaptation of Biometrics Security technologies

RQ 5: Evaluating the biometrics system.

\subsection{Search Process}

Based upon the above research questions, we derived some initial keywords. These initial keywords help to further derive some new alternative keywords by using the search Engines as described in Table 1. 
Irfan Iqbal, International Journal of Advanced Trends in Computer Science and Engineering, 10(1), January - February 2021,321 - 326

Table 1: Search hits on different databases for research questions

\begin{tabular}{|c|c|}
\hline $\begin{array}{l}\text { Main } \\
\text { Keywords }\end{array}$ & $\begin{array}{l}\text { Biometrics, Biometrics Security } \\
\text { Concerns, Biometrics privacy concerns, } \\
\text { Biometrics Security Evaluation, } \\
\text { Biometrics Security Evolution, } \\
\text { Biometrics security Adoption, } \\
\text { biometrics Security solutions, biometrics } \\
\text { security issues, multimodal biometrics }\end{array}$ \\
\hline $\begin{array}{l}\text { Alternative } \\
\text { Keywords }\end{array}$ & 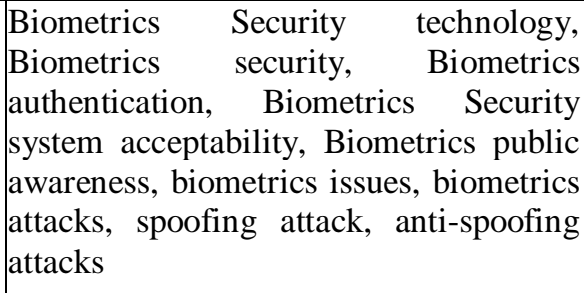 \\
\hline $\begin{array}{l}\text { Different } \\
\text { Publishers/ } \\
\text { Organization }\end{array}$ & $\begin{array}{l}\text { Elsevier, } \text { Science Direct, Emerald, } \\
\text { Springer, Ei Village, ACM, Google } \\
\text { Scholar }\end{array}$ \\
\hline
\end{tabular}

Before deciding either we will include or exclude relevant papers we always go through the contents of the papers/articles like abstract and conclusion and do the little bit skimming. We have defined the criteria of including and excluding article on the following ways.

*We consider only those papers/articles that discuss our research area in detail.

*We consider the papers which published between 2000 and 2020.

*We only consider the articles that are mostly related to biometrics security issues and threats and different anti spoofing attack and countermeasures against the attack.

*We exclude those papers which have no citation and also those who published in 2009 because of the immaturity.

*We try to consider those paper/article whose authors are actively involved or attached with particular area of research.

*We try to include those paper/articles that are reviewed by two or three authors.

During the selection of the papers/articles that are relevant to problem domain and very close to the investigated area. We analyze the creditability of the author with help of tool "Harzing's Publish or Perish"[42].

\section{STATE OF THE ART}

Nowadays there is threat of international Terrorism, high level of security measures are enforced to make fool proof check on the people who crossing the borders. There are lots of techniques which can easily fool biometrics authentication system. But some smart and efficient work is still going on in the biometrics system. Like facial biometrics System capable of creating a facial 'DNA'[43].

\section{HISTORICAL IMPORTANCE}

Table 2 [44]: History of Biometrics Research

\begin{tabular}{|c|c|}
\hline Year & Description \\
\hline 1858 & $\begin{array}{l}\text { First Systematic capture of hand images for } \\
\text { identification purposes is recorded }\end{array}$ \\
\hline 1870 & $\begin{array}{l}\text { Bertillon develops anthropometrics to identify } \\
\text { individuals }\end{array}$ \\
\hline 1896 & $\begin{array}{l}\text { Henry develops a finger print classification } \\
\text { system }\end{array}$ \\
\hline 1936 & $\begin{array}{l}\text { Concept of using the iris pattern for } \\
\text { identification }\end{array}$ \\
\hline 1963 & $\begin{array}{l}\text { a research paper on finger print automation } \\
\text { published }\end{array}$ \\
\hline 1965 & Automated signature research begins \\
\hline 1969 & $\begin{array}{l}\text { FBI pushes to make finger print recognition } \\
\text { an automated process }\end{array}$ \\
\hline 1974 & $\begin{array}{l}\text { First commercial hand geometry system } \\
\text { become available }\end{array}$ \\
\hline 1986 & Exchange Finger print data is published \\
\hline 1992 & $\begin{array}{l}\text { Biometric Consortium is Established within } \\
\text { US Govt }\end{array}$ \\
\hline 1997 & $\begin{array}{l}\text { Generic biometric interpretability standard is } \\
\text { published }\end{array}$ \\
\hline 1998 & FBI launches DNA database \\
\hline 2002 & $\begin{array}{l}\text { ISO Standards Committee established on } \\
\text { Biometrics }\end{array}$ \\
\hline 2004 & $\begin{array}{l}\text { Introduce personal identification card for all } \\
\text { federal employees and contractors }\end{array}$ \\
\hline 2005 & $\begin{array}{l}\text { Iris on the Move is announced at Biometrics } \\
\text { Consortium Conference }\end{array}$ \\
\hline 2008 & $\begin{array}{l}\text { U.S. Government } \quad \text { begin } \\
\text { biometric database use }\end{array}$ \\
\hline 2013 & $\begin{array}{l}\text { Apple includes fingerprint scanners into } \\
\text { consumer-targed smartphones }\end{array}$ \\
\hline
\end{tabular}

\section{CURRENTLY AT THE FOREFRONT OF THE RESEARCH AREA}

Privacy and Personalization are the forefront issue in the society. As everyone consider biometrics technology as a safe tool of security. But there are several issues with Biometrics identification system. The first is unimodal 
Irfan Iqbal, International Journal of Advanced Trends in Computer Science and Engineering, 10(1), January - February 2021,321 - 326

biometrics is fail to reach the performance level. Researcher have been the forefront of developing screen system and imaging system custom fit clothing using holographic radar imaging techniques. In this system radar signal are used which can easily penetrate into the body and reflect of the water in skin. This system implemented on the security check points.

\section{FUTURE WORK AREAS}

Biometrics system developers start working on multimodal biometrics authentication system, to provide a high level of security. Now a day Hitachi's progress toward the multimodal biometrics system named "Advance Digital Person Authentication System"[45]. Biometrics system developer further develops "3-D infrared facial recognition" and "Visitor management System" [46].

In future there are also some standard that are defined for the growth of biometric technology so this will guide the vendors and developers to develop the standard product [46].

\section{RESEARCHER PIONEERS IN THE AREA}

M.Trauring was the pioneer who publish very first research paper in this area in 1963 at "Hughes Research Laboratory".

\section{RESEARCHER ACTIVE TODAY}

Well number of researcher who currently working on the biometrics technology and there issues. In my research I found some of the researcher who is actively working in this field. Some of them Anil K Jain and David Zhang.

Anil K Jain is a university professor in the department of computer science at Michigan State University. He researched on pattern recognition, computer vision and biometric recognition. His articles or papers related to biometrics are published in Scientific American, Nature, IEEE Spectrum, Comm.ACM, IEEE Computer and MIT Technology Review [47].

David Zhang is the director of biometrics technology center supported in 1998. He is the founder and editor in chief of 'International Journal of Image and Graphics' and also book editor of 'Springer International Series on Biometrics'. He is the first organizer of 'International Conference on Biometrics Authentication'. He is the author of more than 10 books and 200 journals [48].

\section{CONFERENCES AND JOURNALS WHERE YOUR ARTICLES HAVE BEEN PUBLISHED}

Table 3: Conferences and Journal articles

\begin{tabular}{|c|c|c|c|}
\hline Ref & Date & $\begin{array}{l}\text { Article } \\
\text { /Paper } \\
\text { Type }\end{array}$ & Conference/Journal Name \\
\hline$[1]$ & 2004 & JA & Biometric Technology Today \\
\hline$[2]$ & 2003 & JA & IEEE Security and Privacy \\
\hline$[3]$ & 2006 & JA & Information Security Technical Report \\
\hline$[4]$ & 2007 & JA & Computers \& Security \\
\hline$[5]$ & 2002 & & Logistics Information Management \\
\hline$[6]$ & 2004 & & An economics view of biometrics \\
\hline [7] & 2008 & $\mathrm{JA}$ & Marketing \\
\hline$[8]$ & 2006 & JA & Sensor Review \\
\hline [9] & 2004 & JA & Biometric Technology Today \\
\hline$[10]$ & 1994 & JA & Information Technology \& people \\
\hline$[11]$ & 1995 & $\mathrm{JA}$ & Computers \& Security \\
\hline$[12]$ & 2003 & JA & Computer Fraud \& Security \\
\hline$[13]$ & 2007 & JA & Computer Fraud \& Security \\
\hline$[14]$ & 2009 & JA & Journal on Multi model user interface \\
\hline$[15]$ & 2005 & $\mathrm{CA}$ & ITHET 6th International conference \\
\hline$[16]$ & 2001 & JA & Computer Law \& Security Report \\
\hline$[17]$ & 2008 & JA & Computer Law \& Security Report \\
\hline$[18]$ & 2006 & JA & Managing Service Quality \\
\hline$[19]$ & 2009 & $\mathrm{JA}$ & Management \\
\hline$[20]$ & 2004 & $\mathrm{CA}$ & $\begin{array}{l}\text { Proc. International Conference on } \\
\text { Pattern Recognition }\end{array}$ \\
\hline$[21]$ & 2004 & JA & Communications of the ACM \\
\hline$[22]$ & 2006 & JA & $\begin{array}{l}\text { IEEE transactions on information } \\
\text { forensics and security }\end{array}$ \\
\hline$[23]$ & 2004 & JA & Sensor Review \\
\hline$[24]$ & 2005 & JA & DOI=etdindividuals.dlib.vt. edu \\
\hline$[25]$ & 2006 & JA & DOI=drdavidlease. com \\
\hline$[26]$ & 2001 & JA & IT Professional \\
\hline$[27]$ & 2009 & $\mathrm{JA}$ & $\begin{array}{l}\text { Computer Law and Security Review: } \\
\text { The International Journal of } \\
\text { Technology and Practice }\end{array}$ \\
\hline$[28]$ & 2000 & JA & Biometric Technology Today \\
\hline$[29]$ & 2007 & $\mathrm{CA}$ & $\begin{array}{l}\text { SPIE - The International Society for } \\
\text { Optical Engineering }\end{array}$ \\
\hline$[30]$ & 2006 & JA & IEEE internet computing \\
\hline$[31]$ & 2009 & $\mathrm{JA}$ & $\begin{array}{l}\text { International Journal of Contemporary } \\
\text { Hospitality Management }\end{array}$ \\
\hline$[32]$ & 2000 & JA & Computer \\
\hline$[33]$ & 2005 & $\mathrm{JA}$ & $\begin{array}{l}\text { Information management and } \\
\text { computer security }\end{array}$ \\
\hline
\end{tabular}


Irfan Iqbal, International Journal of Advanced Trends in Computer Science and Engineering, 10(1), January - February 2021,321 - 326

\begin{tabular}{|c|c|c|c|}
\hline$[34]$ & 2003 & $\mathrm{JA}$ & Pattern recognition letter \\
\hline [35] & 2004 & CA & Citeseer \\
\hline [36] & 2008 & $\mathrm{JA}$ & Kybernetes \\
\hline [37] & 2002 & JA & Information security technical report \\
\hline$[38]$ & 2008 & JA & $\begin{array}{l}\text { Information and management and } \\
\text { computer security }\end{array}$ \\
\hline [39] & 2000 & $\mathrm{JA}$ & Computer \\
\hline [40] & 1997 & $\mathrm{CA}$ & Lecture note in computer science \\
\hline [41] & 2004 & JA & $\begin{array}{l}\text { Information management and } \\
\text { computer security }\end{array}$ \\
\hline [49] & 2011 & $\mathrm{JA}$ & Intention to Use Biometric Systems \\
\hline$[50]$ & 2011 & $\mathrm{JA}$ & $\begin{array}{l}\text { Customers' Adoption of Biometric } \\
\text { Systems in Restaurants: An Extension } \\
\text { of the Technology Acceptance Model }\end{array}$ \\
\hline$[51]$ & 2013 & JA & $\begin{array}{l}\text { Secure Biometrics: Concepts, } \\
\text { Authentication Architectures, and } \\
\text { Challenges }\end{array}$ \\
\hline$[52]$ & 2017 & JA & $\begin{array}{l}\text { Evolution of Biotechnology and } \\
\text { Information Technology and Its } \\
\text { Impact on Human Security }\end{array}$ \\
\hline$[53]$ & 2018 & $\mathrm{JA}$ & $\begin{array}{l}\text { BIOMETRIC TECHNOLOGY: } \\
\text { SECURITY AND PRIVACY }\end{array}$ \\
\hline$[54]$ & 2018 & $\mathrm{JA}$ & $\begin{array}{l}\text { Biometric template security: an } \\
\text { overview }\end{array}$ \\
\hline$[55]$ & 2020 & JA & The latest evolution of biometrics \\
\hline$[56]$ & 2020 & JA & $\begin{array}{l}\text { A review on performance,security and } \\
\text { various biometric template protection } \\
\text { schemes for biometric authentication } \\
\text { systems }\end{array}$ \\
\hline$[57]$ & 2020 & JA & $\begin{array}{l}\text { Addressing biometrics security and } \\
\text { privacy related challenges in China }\end{array}$ \\
\hline
\end{tabular}

*JA: Journal Article

*CA : Conference Article

\section{CONCLUSION}

This paper describes the stages for selecting, searching and refining the valid material for the specified research area. It also helps for assessing the quality of the searched material. We adopted self-created search strategy such as $(\rightarrow$ Define Keyword $\rightarrow$ Choose sources $\rightarrow$ Search technique $\rightarrow$ Evaluate the search results $\rightarrow$ Document selection $\rightarrow$ Reference Management $\rightarrow$ Formulate Information Problem ${ }^{\wedge}$ )

\section{ACKNOWLEDGEMENT}

The author would like to express his deep sense of gratitude to Professor Dr. Ali bin Ibrahim alahdam, and Professor Dr. Yasir bin Muhammad bin Saleh Alghafeeli who led all the research stages and provided insight and invaluable expertise that greatly assisted the research. My thanks are due to Dr.
Awad bin Dhawi Al-Harbi for constant inspiration and valuable advices.

\section{REFERENCES}

[1] Ashbourn, J. 2004. Where we really are with biometrics. Biometric Technology Today 12, 4 (2004), 7-9. DOI=http://www.sciencedirect.com/science/article/B6W 70

$-4 \mathrm{C} 1 \mathrm{C} 7 \mathrm{SW}$ H/2/38ffc75944909cfb490a7a4e9111a844

[2] Bernecker, O.2006. Biometrics security: An end user perspective. Information Security Technical Report 11, 3 (2006), 111-118. DOI=

http://www.sciencedirect.com/science/article/B6VJC4KPGS0Y-2/2/393610dc3668a241b2c8b32d5d7b4805

[3] Bolle, R.M., Connell, J.H., and Ratha, N.K.2002. Biometric perils and patches. Pattern Recognition 35, 12 (2002), 2727-2738.

DOI=http://www.sciencedirect.com/science/article/B6V $14-$

4502W33-1/2/11a1f87771b2e8ccd37420c32a9aa07a

[4] Roberts, C. 2007. Biometric attack vectors and defences. Computers \& Security 26, 1 (2007), 14-25.

DOI=http://www.sciencedirect.com/science/article/B6V $8 \mathrm{G}$

-4MNYYTW-3/2/1ffddfaf7b1b87d854d5706d9e2ebf13

[5] Brooks, W.J., Warren, M.J., and Hutchinson, W.2002. A security evaluation criteria. Logistics Information Management 15, 5/6 (2002), 377-384.

DOI=http://www.emeraldinsight.com/Insight/ViewCont ent

Servlet?Filename=Published/EmeraldFullTextArticle/Ar tic

les/0880150506.html

[6] Cave, J. 2005. An economics view of biometrics. Biometric Technology Today 13, 5 (2005), 8-11 DOI=http://www.sciencedirect.com/science/article/B6W 70

-4GD43Y8-N/2/90b79d2dc8407822571dca3e47e9c545

[7] Chandra, A., Durand, R., and Weaver, S. 2008. The uses and potential of biometrics in health care. Marketing 2, $1 \quad$ (2008), 22-34. DOI=http ://assets. emeraldinsight.com/Insight/ viewC ontent Item.do?contentType $=$ Article \&amp; hdAction $=\operatorname{lnkhtml}$ \&a mp; contentId=1718605\&amp; history=false

[8] Connolly, C. 2006. Performance testing of commercial biometric systems. Sensor Review 26, 1 (2006), 33-37

DOI=http://www.emeraldinsight.com/Insight/ViewCont ent

Servlet?Filename $=$ Published/EmeraldFullTextArticle/Ar tic

les/0870260105.html

[9] Coventry, L. 2004. Biometrics, self-service and the user. Biometric Technology Today 12, 10 (2004), 7-9.

DOI=http://linkinghub.elsevier.com/retrieve/pii/S09694 765

04002292

[10] Davies, S.G. 1994.Touching Big Brother. Information Technology \& People 7, 4 (1994), 38-47.

[11] Deane, F., Barrelle, K., Henderson, R., and Mahar, D. 1995. Perceived acceptability of biometric security systems. Computers \& Security 14, 3 (1995), 225-231. 
Irfan Iqbal, International Journal of Advanced Trends in Computer Science and Engineering, 10(1), January - February 2021,321 - 326

DOI=http://www.sciencedirect.com/science/article/B6V $8 \mathrm{G}$

$-3 \mathrm{Y} 45 \mathrm{THW}-$

5Y/2/819d7b68cc954f0d0906686463e1a421

[12] Forte, D.2003. Biometrics: future abuses. Computer Fraud \& Security 2003, 10 (2003), 12-14. DOI=http://www.sciencedirect.com/science/article/B6V $\mathrm{N}$ T-49V9RY28/2/2dec7ad4e4c40192db0210c2d08728b9

[13] Furnell, S. and Evangelatos, K. 2007. Public awareness and perceptions of biometrics. Computer Fraud \& Security 2007, 1 (2007), 8-13.

DOI=http://www.sciencedirect.com/science/article/B6V NT $\quad-4 \mathrm{MY} 2019-6 / 2 / 90 f 8 b 7 f e 0 c 3 \quad 5$ 5b10be523192e8e13134

[14] Goudelis, G., Tefas, A., and Pitas, I. Emerging biometric modalities: a survey. Journal on Multimodal User Interfaces, 1

19.DOI=http://www.springerlink.com/content/44m7441 $8 \mathrm{u} 58 \mathrm{k}$

1895/fulltext.pdf

[15] Green, N. and Romney, G.W. 2005.Establishing public confidence in the security of fingerprint biometrics. Information Technology Based Higher Education and Training, 2005. ITHET 2005. 6th International Conference on, (2005), S3C.

DOI=http : ://ieeexplore .ieee.org/stamp/stamp. jsp?arnumber $=1560332$ \&isnumber $=33131$

[16] Grijpink, J. 2001. Privacy Law Biometrics and privacy. Computer Law \& Security Report 17, 3 (2001), 154160.

DOI=http://www.sciencedirect.com/science/article/B6V B3 -43GH45H4/2/a6c547b54ccf1537fc283a4868b3be82

[17] Grijpink, J.2008. Trend report on biometrics: Some new insights, experiences and developments. Computer Law \& Security Report 24, 3 (2008).

[18] Heracleous, L. and Wirtz, J. Biometrics: the next frontier in service excellence, productivity and security in the service sector. Managing Service Quality 16, 1 (2006), 12.

[19] Jackson, L.A. 2009.Biometric technology: the future of identity assurance and authentication in the lodging industry. Management 21, 7 (2009), 892-905.

[20] Jain, A.K., Pankanti, S., Prabhakar, S., Hong, L., Ross, A., and Wayman, J.L.2004. Biometrics: a grand challenge. Proc. Interntaional Conference on Pattern Recognition, (2004), 935-942

[21] Jain, A.K. and Ross, A. 2004. Multibiometric systems. Communications of the ACM 47, 1 (2004), 40.

DOI= http://doi.acm.org/10.1145/962081.962102

[22] Jain, A.K., Ross, A., Pankanti, S., and others. 2006.Biometrics: a tool for information security. IEEE transactions on information forensics and security 1, 2 (2006), 125-143.

[23] Kochan, A.2004. Breakthrough in Biometrics. Sensor Review 24, 2 (2004), 125-128.

[24] Lease, D.R.2005. Factors Influencing the Adoption of Biometric Security Technologies by Decision Making Information Technology and Security Managers. (2005).
[25] Lease, D.R. 2007.Enhancing Security in the Private Sector with Biometric Technologies: Problems and Prospects. October 5, (2006), 2007.

[26] Liu, S. and Silverman, M. 2001. A practical guide to biometric security technology. IT Professional 3, 1 (2001), 27-32.

[27] Liu, Y. 2009 The principle of proportionality in biometrics: Case studies from Norway. Computer Law and Security Review: The International Journal of Technology and Practice 25, 3 (2009), 237-250.

[28] Loranger, P.2000. US Army formulates its future biometric strategy. Biometric Technology Today 8, 5 (2000), 3-3.

[29] McMakin, D.L., Sheen, D.M., Hall, T.E., Kennedy, M.O., and Foote, H.P. 2007. Biometric identification using holographic radar imaging techniques. Proceedings of SPIE, (2007), 65380C.

DOI Link: http://dx.doi.org/10.1117/12.729636

[30] Mills, J.E. and Byun, S.2006. Cybercrimes against Consumers: Could Biometric Technology Be the Solution? IEEE internet computing 10, 4 (2006), 64-71.

[31] Murphy, H.C. and Rottet, D. 2009. An exploration of the key hotel processes implicated in biometric adoption. International Journal of Contemporary Hospitality Management 21, (2009).

[32] Phillips, P.J., Martin, A., Wilson, C.L., and Przybocki, M. 2000. An introduction to evaluating biometric systems. Computer, (2000), 56-63.

[33] Riley Jr, R.A. and Kleist, V.F. 2005. The biometric technologies business case: a systematic approach. Information Management \& Computer Security 13, 2 (2005), 89-105.

[34] Ross, A. and Jain, A. 2003. Information fusion in biometrics. Pattern Recognition Letters 24, 13. (2003), 2115-2125.

DOI=http://www.sciencedirect.com/science/article/B6V $15-$

48N31PN-8/2/4296d07cfa90500427b755758bdeb1be

[35] Ross, A. and Jain, A.K. 2004. Multimodal biometrics: An overview. Proceedings of 12th European Signal Processing Conference, (2004), 1221-1224.

[36] Rudall, B.H. and Mann, C.J.H. 2008. New initiatives for new technologies. Kybernetes 37, 7 (2008), 1059 1065.

[37] Schuckers, S.A.2002 Spoofing and anti-spoofing measures. Information Security technical report 7, 4 (2002), 56-62.

[38] Venkatraman, S. and Delpachitra, I.2008. Biometrics in banking security: a case study. Information Management \& Computer Security 16, 4 (2008), 415-430.

[39] Wayman, J.L. 2000.Federal biometric technology legislation. Computer, (2000), 76-80.

[40] Wirtz, B. 1997. Technical evaluation of biometric systems. Lecture notes in computer science, (1997).

[41] Zorkadis, V. and Donos, P. 2004. On biometrics-based authentication and identification from a privacyprotection perspective. Information Management and Computer Security 12, 1 (2004), 125-137.

[42] Harzing 2009. Publish or Perish, version (2.73), 
Irfan Iqbal, International Journal of Advanced Trends in Computer Science and Engineering, 10(1), January - February 2021,321 - 326

available at www.harzing.com/pop.htm

[43] Science Daily. (Nov. 16, 2009). DOI= http://www.sciencedaily.com/releases/2009711/0911111 213 58.htm

[44] Biometric History.2006. National Science and Technology Council. August 2006 DOI=http://www.biometrics.gov/Documents

[45] Isobe, Y.2005. Multimodal Biometrics System. "Personal Authentication Infrastructure for the Ubiquitous Information Age" .July 2005. DOI= http://www.hitachi.com/rd/sdl/people

[46] Osborn, A. 2005. The future of biometrics, "Trends and emerging uses for biometric technology" August 2005. DOI= http://www.video-surveillance-guide.com/futureof- biometrics.htm

[47] DOI=http://www.cse.msu.edu/ jain/

[48] DOI=http://www4.comp.polyu.edu.hk/ csdzhang

[49] Ngugi, B., et al. (2011). "Intention to Use Biometric Systems." e-Service Journal 7(3): 20-46.

[50] Morosan, C. (2011). "Customers' Adoption of Biometric Systems in Restaurants: An Extension of the Technology Acceptance Model." Journal of Hospitality Marketing \& Management 20(6): 661-690.
[51] Rane, S., et al. (2013). "Secure Biometrics: Concepts, Authentication Architectures, and Challenges." IEEE Signal Processing Magazine, Signal Processing Magazine, IEEE, IEEE Signal Process. Mag. 30(5): 5164.

[52] Zinovieva, E. S. and Y. I. Vojtenko (2017). "Evolution of Biotechnology and Information Technology and Its Impact on Human Security." Vestnik MGIMOUniversiteta(5(44)): 154-161.

[53] Krishan, R. and R. Mostafavi (2018). "BIOMETRIC TECHNOLOGY: SECURITY AND PRIVACY CONCERNS." Journal of Internet Law 22(1): 19-23.

[54] Naveed, R., et al. (2018). "Biometric template security: an overview." Sensor Review 38(1): 120-127.

[55] Bhalla, A. (2020). "The latest evolution of biometrics." Biometric Technology Today 2020(8): 5-8.

[56] Sarkar, A. and B. K. Singh (2020). "A review on performance,security and various biometric template protection schemes for biometric authentication systems." Multimedia Tools \& Applications 79(37/38): 27721-27776.

[57] SumYu, M. and A. Kumar (2012). Addressing biometrics security and privacy related challenges in China, IEEE: 1-8. 